\title{
Вадим Денисенко
}

\section{ВІКТОР ЯНУКОВИЧ: ПОЧАТОК ПОЛІТИЧНОЇ КАР’ЕРИ}

Анотація: У статі подана коротка характеристика публікацій на сторінках яких відтворено біографію четвертого Президента України - В. Януковича. Відштовхуючись від иих робіт і залучивши нові джерела, нами була здійснена спроба реконструкиії перших етапів його політичної біографії. На підставі аналізу доступних документів і свідчень, критично переосмислюємо наявні теорії та припущення відносно кримінального переслідування В.Януковича у 1970-х роках, подальшого його засудження й ув'язнення. Звертаємо увагу на особливості процесу «погашення» иих судимостей.

Показано взаємозв'язок кримінального досвіду набутого В. Януковичем у пізньорадянський період і подальшим, стрімким просування його владною драбиною. Припускаємо, що таке стрімке входження до політичних еліт регіону було обумовлене співпращею із “силовиками».

На підставі політичного аналізу розподілу впливу між різними фінансово-промисловими групами початку 1990-х років обгрунтовуємо твердження проте, що перехід В. Януковича у «велику політику" був обумовлений домовленостями між Президентом Л.Кучмою та представниками донецької фінансово-промислової групи. Нами зроблена спроба показати, що пролобіювавши на посаду прем'єр-міністра України В.Януковича, представники донецької фінанси-промислової групи не мали повного контролю над цим Урядом, оскільки ключові посади у ньому належали орієнтованим на Президента Л. Кучму акторам.

На підставі аналізу структури, кадрової політики, особливостей розподілу повноважень між членами Уряду В. Януковича обтрунтовується гіпотеза про те, що голові цього Кабінету міністрів відводилася роль клієнта, який сумлінно виконував вказівки свойх патронів і готувався до боротьби за посаду Президента України.

Ключові слова: Віктор Янукович, донецький клан, Леонід Кучма, прем'єр-міністр, фінансово-промислова група

Важливим етапом у розумінні та осмисленні причин приходу до влади, після розпаду Радянського Союзу, представників колишньої партноменклатури та їх клієнтів спонукає нас до вивчення біографій і політичних траєкторій найбільш впливових політичних діячів. Зокрема, мало дослідженим є процес витіснення «дніпропетровців» і перехоплення політичної ініціативи із подальшим домінування у політичному житті незалежної України 2000-х років акторів, які були ядром донецької фінансово-промислової груп. Одним із найбільш відомих представників цієї групи є четвертий Президент України В. Янукович.

Повноцінно розуміння специфіки формування та функціонування режиму В. Янукович не можливе без дослідження життєвого та політичного шляху самого лідера цього режиму. Перші праці, які висвітлювали біографію В. Януковича почали з'являтися ще

\footnotetext{
"Денисенко Вадим Ігорович - кандидат філологічних наук, докторант Запорізького національного університету (Запоріжжя, Україна); ORCID: https://orcid.org/0000-0003-4317-2884; e-mail: vadva3174@gmail.com
} 
в 2004 р. у ході передвиборчих перегонів за авторства Валентина Чемериса («Загадка Віктора Януковича») ${ }^{1}$, Віталія Спажука («Дійсно творець») ${ }^{2}$ та Віри Ніколаєвої («Доторкнися до долі») $)^{3}$. У них тогочасний прем'єр-міністр був зображений як «людина 3 народу», яка попри життєві труднощі змогла опинитися на вершині управлінської вертикалі. У 2010 р. з'являється нові біографічні розвідки під авторством В.Спажука («Життя під знаком факторіала») $)^{4}$ та Володимира Чередниченка («Національна ідея») ${ }^{5}$. у них В. Янукович постає в образі «захисника церкви», «глибоко набожної людини». Через три роки В. Чередниченко випускає чергову біографічну роботу але вже під однойменною назвою «Віктор Янукович», яка за стилем повторювала відоме багатосерійне російське видання «Життя чудових людей» (рос. «Жизнь замечательных людей»).

Спільним знаменником подібних робіт є спроби переконати читача у об’єктивності і достовірності. Для цього автори підкреслюють власну неупередженість, доступ до ексклюзивної інформації, використовують вирази з наукового сленгу. Однак вибірковий підхід до фактів та відсутність джерельних підтверджень однозначно вказують на ї призначення як PR-інструментів, а не спроб неупередженого аналізу.

Слід констатувати, що наявні роботи мають публіцистичний, а грунтовних, написаних науковцями робіт, на сторінках яких було б реконструйовано біографічний портрет В. Януковича немає.

Віктор Федорович Янукович народився 9 липня 1950 р. у селищі Жуківка поблизу м. Єнакієве Сталінської (зараз Донецької) області. Батько - Федір Володимирович походив з села Януки Вітебської області Білоруської РСР та переселився на Донбас після вигнання нацистів $з$ території України. Згідно з документами, оприлюдненими народним депутатом України Володимиром Яворівським, причиною зміни місця проживання стала співпраця 3 нацистськими окупантами протягом 1941-1944 pp. Працював машиністом паровозу. Мати - Ольга Семенівна Леонова - працювала медсестрою на шахті «Юнком» у селищі Юнокомунарівськ (зараз Бунге) поблизу м. Єнакієве. Померла у 1952 р. В інтервю 2005 р. Віктор Янукович розповідав, що його виховувала бабуся ${ }^{8}$.

Першу версію історії шкільних років Януковича можна знайти в агітаційній брошурі Валентина Чемериса «Загадка Віктора Януковича». Вона побачила світ напередодні Помаранчевої революції у 2004 р. шаленим накладом 12000000 примірників. Згідно 3 баченням автора, четвертий український президент змінив три школи. Спочатку провчився рік у селищі Зарудне (5 км від Жуківки), через рік перейшов у школу селища Тернівка, куди переїхав батько, а згодом перейшов до школи селища Роздолівка, яке пізніше стало

\footnotetext{
${ }^{1}$ Чемерис В. Загадка Віктора Януковича: спроба дослідження. Київ: [б.в.], 2004. 96 с.

${ }^{2}$ Спажук В.И. Истинно созидатель. Донецк: Донеччина, 2004. 224 с.

${ }^{3}$ Николаева В. Прикоснись к судьбе. Виктор Янукович. Донецк: Новый мир, 2004. 96 с.

${ }^{4}$ Спажук B. Жизнь под знаком факториала : дилогия. Донецк: Юго-Восток, 2010. 243 с.

${ }^{5}$ Чередниченко В. Национальная идея: в 3 кн. Кн. 3. Днепропетровск: Монолит, 2010. 376 с.

${ }^{6}$ Чередниченко В. Виктор Янукович. Харьков: Фолио, 2013. 250 с.

${ }^{7}$ Яворівський оприлюднив документи НКВС про те, що батько і дядько Януковича були «пособниками фашистів». Корреспондент. URL: https://ua.korrespondent.net/ukraine/1039747-yavorivskij-oprilyudnivdokumenti-nkvs-pro-te-shcho-batko-i-dyadko-yanukovicha-buli-posobnikami-fashisti

${ }^{8}$ Янукович розповів, які пісні йому співала бабуся. Українська правда. 2005. 21 грудня. URL: https://www.pravda.com.ua/news/2005/12/21/3037072/
} 
частиною Єнакієва9.

Більш правдоподібну версію озвучили журналісти видання «КП в Украине», які в 2010 р. розшукали ряд документів про середню освіту Януковича та кількох очевидців. За ними, першим навчальним закладом майбутнього президента стала школа № 16 м. Єнакієве. У 1959 р. родина Януковичів переїхала з Жуківки до Роздолівки (нині район Єнакієва). Як наслідок, його перевели до школи № 34, яку він закінчив у 1965 р. На користь своєї версії журналісти навели книгу обліку учнів та книгу наказів школи № 16, а також свідчення працівників навчального закладу ${ }^{10}$.

Здобувши атестат, Янукович вступив до Єнакієвського гірничого технікуму на відділення «Гірнича електромеханіка». Під час навчання він був засуджений до трьох років позбавлення волі за участь у пограбуванні. За амністією строк був зменшений до 1 року та 7 місяців. 3 них Янукович відбув 7 місяців та був звільнений достроково за зразкову поведінку. На думку колишнього арештанта Єнакієвської колонії №52 Миколи Московченка, молодий ув'язнений співпрацював з адміністрацією в'язниці і це допомогло йому вийти з колонії раніше ${ }^{11}$.

Нетривалий час на волі Янукович працював електрогазозварювальником на Єнакієвському металургійному заводі. На ньому він познайомився зі своєю майбутньою дружиною Людмилою. Однак вже 8 червня 1970 р. він був вдруге засуджений за нанесення тілесних ушкоджень середньої тяжкості до 2 років позбавлення волі. Обставини другої судимості Віктора Федоровича також є неоднозначними. За однією з версій, постраждалою була дівчина, згвалтована Януковичем та його товаришем, однак доказів на їі користь немає $\epsilon^{12}$. Друге покарання він відбував протягом двох років у Єнакієвській виправній колонії № 52 .

Після другого звільнення життєва траєкторія Януковича різко змінюється. У 1972 р. він влаштовується на роботу автоелектриком та одружується з Людмилою Настенко. За рік народний суд м. Єнакієве, який на той час очолював дядько дружини Януковича, знімає 3 нього обидві судимості.

Очищений перед радянською владою майбутній донецький політик розпочинає робити серйозні кроки вгору кар'єрною драбиною. Влаштовується механіком на Єнакіївське автотранспортне підприємство № 04113. У липні 1974 р. 3 першої спроби стає студентом заочного відділення Донецького політехнічного інституту. Через два роки, студент другого курсу 3 двома судимостями стає директором автобази виробничого обєєнання «Орджонікідзевугілля».

Різкий поворот у життєвій траєкторії Януковича суперечив логіці функціонування радянської системи, яка ретельно фільтрувала як претендентів на керівні посади, так i майбутніх студентів. Ще більш незвичайними виявилися наступні віхи у біографії колишнього арештанта. У 1978 р. до Донецького обласного суду начебто звертається

\footnotetext{
${ }^{9}$ Чемерис В. Загадка Віктора Януковича: спроба дослідження...

${ }^{10}$ Коник А. Как учился и вел себя Янукович в первом классе. КП в Украине. 2010. 1 сентября. URL: https://kp.ua/politics/241795-kak-uchylsia-y-vel-sebia-yanukovych-v-pervom-klasse

${ }^{11}$ Вікторович Я. «Прєм'єр-міністр» Янукович, або Неофіційна біографія для тих, хто підзабув. Украӥнська правда. 2006. 4 серпня. URL: https://www.pravda.com.ua/articles/2006/08/4/3141018/

${ }^{12}$ Ibidem.
} 
депутат Верховної Ради СРСР, льотчик-космонавт Георгій Береговий 3 проханням реабілітувати Віктора Януковича. Несподіване прохання пізніше породило кілька легенд. За першою 3 них, батько Януковича дружив з легендарним космонавтом і у скрутний час той допоміг непутящому синові друга. Це видається неможливим, адже Береговий займався в Єнакієвському аероклубі наприкінці 1930-х рр., а Федір Янукович за архівними документами потрапив на Донбас не раніше 1945 р. Ще більш оригінальною виявилася версія про Віктора Януковича як позашлюбного сина космонавта, на користь якої немає жодного доказу.

Ці легенди почали поширюватися у публічному просторі після розголошення відомостей про судимості Прем'єр-міністра України 2002-2005 рр. Вони виглядають більше як спроби незграбного пояснення ролі Берегового у відмиванні Януковича. Власне сам факт звернення та скасування судимостей у 1978 р. також піддають сумніву. 11 липня 2005 р. прокуратура відкрила кримінальне провадження щодо підробки документів. Проведена експертиза архівної справи № 386 Р-3410 Донецького обласного суду виявила:

1) аркуші з постановами про відміну вироків Януковичу були підшиті до справи після розшивання інших аркушів;

2) постанови надруковані на іншому папері та на іншій друкарській машинці, аніж усі інші аркуші у справі;

3) підписи судді-доповідача Віталія Хованського були виконані іншою особою ${ }^{13}$.

3 архіву Єнакієвського міського суду зникли обвинувальні вироки щодо Януковича 1967 та 1970 рр. начебто через відсутність належної охорони протягом 1989-2000 рр. Тому кримінальна справа 2005 р. була закрита через відсутність достатніх доказів та через закінчення строків притягнення до кримінальної відповідальності. Сам факт підробки не був спростований. На нашу думку, найбільш вірогідною на даний момент версією є фальсифікація реабілітації Януковича наприкінці 1990-х - початку 2000-х рр. задля створення позитивного іміджу впливовому донецькому політику.

Тим не менш, темні плями на біографії четвертого українського Президента не вичерпуються таємничою реабілітацією 1978 р. Ще більш дивним виглядає його вступ до КПРС у 1980 р. На цей факт варто звернути особливу увагу. Нагадаємо, що отримання партійного білету за доби СРСР було необхідною умовою для успішного карєеного зростання. Члени партії проходили ретельну фільтрацію. Відповідно до статуту КПРС у редакції 1971 р., що діяв на момент вступу Януковича, претендент на звання комуніста мав пройти кандидатський стаж протягом одного року, надати рекомендації трьох членів партії зі стажем не менше пяти років. Партійна організація проводила перевірку «політичних, ділових та моральних якостей» кандидата. Про вплив кримінальних справ на перспективи перебування у складі КПРС неоднозначно вказує п. 12 статуту: «Якщо член партії зробив проступки, що караються в кримінальному порядку, він виключається 3 партії i притягується до відповідальності відповідно до Закону» ${ }^{14}$.

Пояснити факт надзвичайно лояльного ставлення до Януковича з боку радянської

\footnotetext{
${ }^{13}$ Лещенко С. Як скасували судимості Януковича. Документи публікуються вперше. Українська правда. 2010. 14 січня. URL: https://www.pravda.com.ua/articles/2010/01/14/4618441/

${ }^{14}$ Устав Коммунистической партии Советского Союза: утвержден XXII съездом, частичные изм. внесены XXIII и XXIV съездами КПСС. Москва: Политиздат, 1976. 128 с.
} 
системи неможливо без гіпотези про його співпрацю з органами державної безпеки. На нашу думку, під час ув'язнення він розпочав співпрацю з КДБ і ймовірно мав виконувати роль підконтрольного чекістам лідера організованої злочинної групи. Використовуючи жаргон кримінального світу, Янукович, скоріше за все, був «консервою» КДБ, яку активно підтримували та допомагали рухатися вгору по кар'єрній драбині. А космонавт Георгій Береговий був просто символічною фігурою (на зразок «вічного» зіцголови Фунта 3 твору Іллі Ільфа та Євгена Петрова), яку попросили підписати відповідного листа.

Подальша біографія Януковича демонструє швидкий кар'єрний злет колишнього в'язня. У 1982 р. його обирають депутатом Карло-Марксівської сільської ради м. Єнакієве. Через 2 роки він стає директором центральної автобази тресту «Донбастрансремонт». У вересні 1987 р. його призначають заступником директора 3 матеріально-технічного забезпечення та транспорту державного виробничого об'єднання «Донецькдержвуглепром». 1989 р. він стає в.о. директора виробничого об'єднання «Донбастрансремонт», а у 1991 р. - генеральним директором цього підприємства ${ }^{15}$. Цілком ймовірно, що роль у такому стрімкому зростанні неоднозначного управлінця зіграв Юрій Іванющенко.

Розпад радянської системи та проголошення незалежності України Віктор Янукович зустрів молодим енергійним керівником (у 1991 р. йому виповнилося 41 рік) на чолі одного 3 потужних підприємств Донецької області. «Донбастрансремонт» мало у розпорядженні дефіцитні на початку 1990-х рр. автозапчастини та паливо, що надавало його очільникам значної ресурсної ваги. Його можна віднести до тієї генерації радянських номенклатурних працівників, що з ентузіазмом зустріла перехід від планової до ринкової економіки. Для них відкривалася можливість конвертувати адміністративні повноваження у більш надійну приватну власність та якісно інший спосіб життя. Якщо керівна посада поєднувалася 3 широкою мережею неформальних зв'язків, то керівник отримував можливість здійснити різкий стрибок у соціальному статусі.

Про період у житті Януковича з 1991 до 1997 рр. відомо вкрай мало. У інформаційному просторі можна знайти свідчення про те, що він став автором прибуткової схеми «вугілля-кокс-метал». Вона полягала у отриманні державних субсидій для видобутку вугілля, виробництво коксу з нього та виробництві більш дешевого металу за рахунок меншої собівартості сировини ${ }^{16}$. Попри те, що така схема дійсно виникла у 1990-х рр., підтверджень причетності власне Віктора Януковича до неї немає. Більше того, взагаді складно повірити, що Янукович міг вигадати цю схему (за іншою більш вірогідною версією автором цієї схеми був Віталій Гайдук). Достеменно відомо лише про те, що він продовжив керувати одним з найбільш крупних підприємств Донецька у сфері автотранспорту, а у 1994 p. його призначають генеральним директором Донецького територіальновиробничого об'єнання автотранспорту. Воно було створено ще 1988 р. в ході спроб реорганізації планової економіки і продовжувало свою діяльність уже в незалежній Україні.

У серпні 1996 р. розпочався новий етап у політичній кар'єрі Віктора Януковича. Його призначають заступником голови Донецької обласної державної адміністрації, а вже за

\footnotetext{
${ }^{15}$ Офіщійна біографія Януковича. Що він написав депутатам. Українська правда. 2006. 4 серпня. URL: https://www.pravda.com.ua/articles/2006/08/4/3141215/

${ }^{16}$ МиндичД. Мова по фене. Профиль: еженедельньй журнал. 2007. №35. URL: https://web.archive.org/web/20070927030239/http://www.profile.ru/items/?item=9789
} 
місяць він стає першим заступником голови. На той момент в Україні йшла гостра боротьба між донецькими фінансово-промисловими колами та новим прем'єр-міністром Павлом Лазаренком. Головною причиною була конкуренція за газовий ринок регіону: Лазаренко лобіював інтереси корпорації «Єдині енергетичні системи України», а донецькі еліти підтримували «Індустріальний союз Донбасу». У ході протистояння посаду втратив голова облдержадміністрації Володимир Щербань, а його місце посів близький до Лазаренка колишній міністр вугільної промисловості Сергій Поляков ${ }^{17}$.

Новий очільник президентської вертикалі в регіоні шукав місцеві кадри для налагодження контактів 3 місцевою верхівкою. Одним 3 таких став Віктор Янукович. За спогадами останнього, на роботу до держадміністрації його запросив сам голова, прохаючи про допомогу ${ }^{18}$. Звідси випливає важливий момент. Янукович пішов на співпрацю 3 представником ворожої фінансово-промислової групи, що намагалася поширити свій вплив на Донбас. Це свідчить або про його слабкі зв'язки 3 донецькою верхівкою (що є малоймовірним $з$ огляду на попередні та подальші взаємини 3 донецькими фінансовопромисловими групами), або про делегування його місцевими кланами для контролю за діями нового «губернатора». На нашу думку, більш вірогідним є другий варіант. Більше того, очевидно, не обійшлося без колишніх «кураторів» радянського КДБ, які мали на той момент тісні стосунки з криміналітетом і лідерами місцевих ФПГ.

Ослаблення позицій Лазаренко підірвало підтримку Сергія Полякова. Вже у травні 1997 р. він втрачає посаду голови облдержадміністрації і його місце автоматично посідає Віктор Янукович ${ }^{19}$. Його перебування на чолі області стало періодом політичної консолідації та подальшого посилення донецьких еліт. За джерелами політолога Костянтина Бондаренка, регіональні еліти Донбасу шукали слухняного виразника своїх інтересів і зупинили свій вибір на Януковичі. Тож він від початку не був самостійним політичним гравцем. Також представники донецького клану, зокрема Віталій Гайдук, уникали відповідей на питання, хто ж лобіював делегування нового голови обласної державної адміністрації ${ }^{20}$. Ця обставина наводить на думку про зв'язки нового очільника Донеччини з кримінальними колами та/або ж з українськими безпековими службами.

у будь-якому разі протягом 1997-2002 рр. регіональні еліти зміцнили свій вплив. Віктор Янукович стає також депутатом Донецької обласної ради в 1998 р. і після відставки голови ради Івана Пономарьова займає його посаду ${ }^{21}$. Мова йшла про поєднання повноважень президентської вертикалі та місцевого самоврядування в одних руках. До адміністративного ресурсу додавалися також фінансові потужності місцевих фінансовопромислових груп та мережа неформальних зв'язків з організованою злочинністю. Усе разом давало донецькому клану практично повний контроль над своїм базовим регіоном.

\footnotetext{
${ }^{17}$ Поляков Сергей Васильевич. URL: http://www.cspr.org.ua/data/185.html\#khar

${ }^{18}$ Янукович каже, що на роботу в органи влади його запросив не Лазаренко. Padio Cвобода. URL: https://www.radiosvoboda.org/a/24916682.html

${ }^{19}$ Про призначення В. Януковича головою Донецької обласної державної адміністрації: Указ Президента України від 14.05.1997 p. № 435/97. Урядовий кур'єр. 1997. 17 травня.

${ }^{20}$ Мусафирова О. «Доны» или «Бригада Януковича». Hовая газета. 2014. 12 марта. URL: https://novayagazeta.ru/articles/2014/03/12/58700-171-dony-187-ili-171-brigada-yanukovicha-187

${ }^{21}$ Хоменко Л. Обирали голову. В голові - вибори. День. 1999. 20 травня. URL: https://day.kyiv.ua/uk/article/podrobici/obirali-golovu-v-golovi-vibori
} 
Ступінь контролю відображали результати виборів на території Донеччини. Зокрема, 1999 р. відбулися чергові вибори Президента України. Згідно 3 соціологічними опитуваннями жителі Донбасу віддавали перевагу кандидатам від лівих сил: Петру Симоненку (Комуністична партія України), Наталії Вітренко (Прогресивна соціалістична партія України) та Олександру Морозу (Соціалістична партія України). Їхній сукупний електорат складав 34\% на фоні 12\% у діючого Президента Леоніда Кучми 22 . Однак за результатами другого туру в області впевнено переміг Леонід Кучма 3 майже 53\% голосів виборців. Досить несподівано на Донеччині він отримав понад 1,5 млн. голосів виборців, що стало суттєвим внеском у його перемогу ${ }^{23}$. Це було б неможливим без співпраці між донецькими фінансово-промисловими групами та Леонідом Кучмою.

На чолі Донецької облдержадміністрації Віктор Янукович підтримував ініціативи місцевого істеблішменту зі збереження та розширення своєї сфери впливу. За його каденції було пролобійовано високі мита на імпортний кокс, що дозволило прибрати конкуренцію для донецьких виробників. Найбільшим викликом для нього та його оточення стали плани прем'єр-міністра Віктора Ющенка та віце-прем'єр-міністра Юлії Тимошенко провести реформу вугільної галузі. У другій половині 1990-х рр. стало очевидним, що існуюча модель функціонування видобутку вугілля знаходиться у глибокій кризі. Про це свідчили низька продуктивність праці шахтарів, висока собівартість вугілля, монополізація поставок сировини кількома фінансово-промисловими групами. Донецькі еліти були зацікавлені у збереженні «статус кво». На фоні активізації спроб змін у вугільній сфері у відставку зі скандалом йде міністр палива та енергетики Сергій Тулуб, тісно пов'язаний з Донбасом ${ }^{24}$. у листопаді 2000 р. Тимошенко виступила 3 ініціативою реформування галузі. Вона передбачала введення повної передплати за відвантажену продукцію, перехід до аукціонів 3 продажу вугілля, зміну керівництва шахт та їх часткову приватизацію 25 . Такий підхід зачіпав інтереси крупних донецьких підприємців, які активно використовували систему державних дотацій та перепродажу вугілля 3 державних шахт для власного збагачення. Розпочалося гостре протистояння між урядом i регіональним керівництвом. Його наслідком стало порушення кримінальної справи й відставка Тимошенко 3 посади віцепрем’єр-міністра ${ }^{26}$ та домовленості Леоніда Кучми 3 донецьким кланом.

На нашу думку, результат домовленостей продемонстрували вибори до Верховної Ради 2002 p. На них мав місце ще більш разючий контраст між соціологічними опитуваннями та результатом виборів, порівняно з президентськими перегонами 1999 р. Донеччина віддала пропрезидентському блоку «За єдину Україну» майже 37\% голосів. У всіх інших без винятку регіонах підтримка цього політичного обєднання не перевищувала 18\%, а у близькій за вподобаннями Луганщині складала скромні $14 \%{ }^{27}$. Тож є всі підстави вести

\footnotetext{
${ }_{22}^{22}$ Політичний портрет України. № 22: Вибори-1999. URL: https://dif.org.ua/article/vibori-99

${ }_{23}^{23}$ Вибори Президента України 1999: інформ.-аналіт. видання / редкол.: М.М. Рябець (голова) та ін. Київ: Преса України, 2000. С. 298.

${ }^{24}$ Тулуб поступився Тимошенко у боротьбі за ПЕК. Украӥнська правда. 2000. 15 червня. URL: https://www.pravda.com.ua/news/2000/06/15/2980718/

${ }^{25}$ Тимошенко оголосила про початок реформи вугільної галузі України. Корреспондент. URL: https://ua.korrespondent.net/ukraine/230232-timoshenko-ogolosila-pro-pochatok-reformi-vugilnoyi-galuzi-ukrayini ${ }^{26}$ Тимошенко звільнено. Українська правда. 2001. 19 січня. URL: https://www.pravda.com.ua/news/2001/01/19/2981698/

${ }^{27}$ Парламентські вибори 2002 р.: результати голосування у багатомандатному виборчому окрузі. URL:
} 
мову про масштабне використання донецькими елітами адміністративного ресурсу для підвищення результату «партії влади».

Того ж року розпочинається новий етап у політичній кар'єрі Віктора Януковича. 16 листопада 2002 р. Леонід Кучма відправляє у відставку Кабінет міністрів на чолі 3 Анатолієм Кінахом ${ }^{28} .21$ листопада він підписує указ про призначення Віктора Януковича прем'єр-міністром України та дає завдання сформувати новий уряд ${ }^{29}$.

Рішення Кучми стало несподіванкою для частини суспільства та експертного середовища. Адже «донецькі» були ключовими конкурентами близького до другого Президента «дніпропетровського клану». Численні свідчення вказують, що Леонід Кучма аргументовано побоювався їх посилення та вживав заходів для обмеження впливу. Остаточні мотиви призначення Віктора Януковича головою уряду в 2002 р. не є однозначно ясними та зрозумілими. За версією головного редактора видання «Дзеркало тижня» Юлії Мостової, Кучма потребував жорсткого виконавця, якого він буде здатним контролювати і який зможе гарантувати йому безпечне майбутнє $\epsilon^{30}$. Інший підхід стверджує, що Кучма був змушений поступитися амбіціям донецьких еліт, які забезпечили провладному блоку результат на парламентських виборах 2002 р. В умовах потенційного союзу «донецьких» та Віктора Ющенка проти діючого Президента він був змушений пожертвувати посадою прем’єр-міністра задля збереження бодай частини своїх позицій ${ }^{31}$.

За іншою версією, Кучма вибудував особистісні стосунки з лідерами більшості ФПГ і фактично вручну «розрулював» всі можливі конфліктні ситуації. Янукович виглядав надслабкою фігурою, до того ж і не дуже розумною. Азаров, який посів місце першого віцепрем'єра, був білыше людиною Кучми, ніж донецьких. Поставивши Януковича, Кучма зробив пас донеччанам, які справді, отримали масу преференцій, але залишив управління всім виключно за собою. Не треба також забувати, що таким чином Кучма тримав своїх найсерйозніших потенційних ворогів поруч з собою, не даючи їм почати грати власні політичні ігри. Тоді ж з'явилося багато чуток про нібито 300 млн доларів, заплачених за посаду прем'єра, але далі чуток ця історія не пішла.

Цікавою була конфігурація нового уряду під керівництвом Віктора Януковича. Віцепрем'єр-міністрами стали Микола Азаров (перший віще-прем'єр та міністр фінансів, ексголова Податкової адміністрації України), Віталій Гайдук (опікувався питання паливноенергетичного сектору, колишній заступник Януковича під час роботи в Донецькій облдержадміністрації), Дмитро Табачник (відповідав за гуманітарний напрямок, колишній голова Адміністрації Президента України) та Іван Кириленко (займався питаннями сільського господарства, раніше працював у Дніпропетровській облдержадміністрації та

https://datatowel.in.ua/elections/parliamentary2002

${ }^{28}$ Про відставку Кабінету Міністрів України: Указ Президента України від 16.11.2002 р. № 1050/2002. Офіційний вісник Украӥни. 2002. № 47. С. 76.

${ }^{29}$ Про призначення В. Януковича Прем'єр-міністром України: Указ Президента України від 21.11.2002 p. № 1051/2002. Урядовий кур ’єр. 2002. 23 листопада.

${ }^{30}$ Мостова Ю. Ігри в Януковича. Дзеркало тижня. 2002. 15 листопада. URL: https://zn.ua/ukr/politcs_archive/igri_v_yanukovicha.html

${ }^{31} 25$ років незалежності: нариси історії творення нації та держави / НАН України; Ін-т історії України. Київ: Ніка-Центр, 2016. С. 280-281. 
міністром аграрної політики України) ${ }^{32}$. Варто зазначити, що на той момент всі віцепрем'єри орієнтувалися перш за все на Президента.

За квотою Президента України до уряду було призначено міністра внутрішніх справ Юрія Смирнова (протягом 1990-х - на початку 2000-х очолював УМВС Луганської, Дніпропетровської областей, м. Київ), міністра оборони Володимира Шкідченка (в минулому командувача Одеським військовим округом та начальника Генерального штабу Збройних сил України), міністра юстиції Олександра Лавриновича (колишній в.о. голови Центральної виборчої комісії та голова міжфракційної депутатської групи з розробки Конституції України) та міністра закордонних справ Анатолія Зленка (досвідченого дипломата, який вже очолював міністерство у 1990-1994 рр. та з 2000 р. $)^{33}$. Також за цією ж квотою зайняв посаду секретар уряду Володимир Яцуба.

Низка міністрів були пов'язані 3 партійними структурами Соціал-демократичної партії України (об’єднаної) - політичного проекту, яким опікувався голова Адміністрації Президента України Віктор Медведчук. До них належали міністр праці та соціальної політики Михайло Папієв (відомий функціонер СДПУ(о) та раніше заступник голови Чернівецької облдержадміністрації), міністр транспорту Георгій Кирпа (генеральний директор Державної адміністрації залізничного транспорту) та міністр освіти і науки Василь Кремень (президент Національної академії педагогічних наук України, на посаді міністра з 1999 р. $)^{34}$.

Міністром охорони здоров'я став Андрій Підаєв, який у 1995-2002 рр. очолював медичну систему Автономної Республіки Крим. Міністром аграрної політики став представник житомирської партійної номенклатури Сергій Рижук, який з 1997 р. працював на різних посадах у даному міністерстві. На посаду міністра промислової політики був призначений «червоний директор» та колишній перший секретар обкому КПУ з Харкова Анатолій М'ялиця (протягом 1990-х рр. він керував Харківським державним авіаційним виробничим підприємством). У спадок від урядів Віктора Ющенка та Анатолія Кінаха Кабміну Януковича дістався міністр палива та енергетики Сергій Єрмілов (у минулому директор «Крименерго», людина Віталія Гайдука). Василь Шевчук (у 1990-і рр. заступник міністра та міністр охорони навколишнього середовища) став на чолі міністерства екології та природніх ресурсів. Міністром культури та мистецтв був призначений Юрій Богуцький, який понад 20 пропрацював на керівних посадах у культурній сфері. Міністром 3 питань надзвичайних ситуацій та у справах захисту населення від наслідків Чорнобильської катастрофи став Григорій Рева (раніше начальник Державного департаменту пожежної безпеки МВС України) ${ }^{35}$.

Наймолодшим членом Кабміну Януковича став 33-річний бізнесмен Валерій Хорошковський, якому доручили опікуватися питаннями економіки та європейської інтеграції ${ }^{36}$.

\footnotetext{
${ }^{32}$ Команда Януковича. https://www.pravda.com.ua/news/2002/11/30/2991825/ (дата звернення: 10.06.2019).

${ }^{33}$ Ibidem.

${ }^{34}$ Ibidem.

${ }^{35}$ Команда Януковича. $\quad$ ккрайнська правда. 2002. 30 листопада. URL: https://www.pravda.com.ua/news/2002/11/30/2991825/

${ }^{36}$ Хорошковский Валерий. ЛІГА. Досье. URL: https://file.liga.net/persons/valerii-horoshkovskii
} 
Аналіз персонального складу першого уряду Януковича вказує на його компромісний характер. I хоча ключові посади у ньому формально отримали представники донецького клану (прем'єр-міністра та 2 віце-прем'єрів), віце-прем'єри, як уже вище зазначалося орієнтувалися перш за все на Леоніда Кучму. Водночас свою частку впливу в Кабміні мали Віктор Медведчук та окремі фінансово-промислові групи. Це дає всі підстави стверджувати, що формування уряду 21 листопада 2002 р. стало результатом підкилимних домовленостей основних груп впливу в оточенні другого Президента України та донецького істеблішменту.

Уряд Януковича продовжив різновекторну політику попередніх Кабмінів. 3 одного боку, виконавча влада декларувала прихильність ідеям євроатлантичної інтеграції. 2003 р. було прийнято закон України «Про основи національної безпеки України», що визначав членство в ЄС та НАТО як один з основних напрямів зовнішньої політики України. Того ж року українські військові підрозділи взяли участь у місії в Іраку. Також продовжував розвивати напрямок співпраці з ЄС у форматі програм ядерної безпеки (ліквідація наслідків Чорнобильської катастрофи), TACIS (підтримка дрібного бізнесу, освіти, наукових досліджень), політики європейського сусідства.

3 іншого боку, уряд Януковича не міг ігнорувати наростаючу ізоляцію режиму Леоніда Кучми на фоні «касетного» ${ }^{37}$ та «кольчужного» ${ }^{38}$ скандалів 3 боку західних партнерів. Це виражалося у підтримці ініціатив Кучми щодо активізації українськоросійських відносин. У вересні 2003 р. в Ялті було підписано угоду про приєднання до Єдиного економічного простору з Росією, Білоруссю та Казахстаном, а сам рік було оголошено «Роком Росії в Україні ${ }^{39}$.

Документи Кабінету міністрів України за листопад 2002 - січень 2005 рр. здатні пролити світло на реальний статус Януковича у вертикалі виконавчої влади. У перші тижні роботи нового уряду була прийнята постанова, що регулювала розподіл обов'язків між головою Кабміну та його заступниками. За нею, на Віктора Януковича покладалися, перш за все, номінальні функції на зразок підписання вже погоджених міжнародних документів, контроль над силовими структурами (які залежали, перш за все, від Президента), Міністерством юстиції та деякими іншими менш значними державними органами. Натомість заступники Януковича отримали значно більше важелів для впливу на ситуацію в країні. Миколі Азарову дісталася опіка над економічним блоком, Віталію Гайдуку паливно-енергетичним комплексом та транспортом, Івану Кириленку - агропромисловим комплексом, Дмитру Табачнику - весь гуманітарний блок ${ }^{40}$.

I якщо розподіл обов'язків можна було б списати на просту бюрократичну тяганину, то поточні документи уряду свідчать саме про обмежену роль Януковича у власному

\footnotetext{
${ }^{37}$ Касетний скандал 2000 р. - оприлюднення записів з Адміністрації Президента Кучми співробітником служби охорони Президента Миколою Мельниченком, які свідчили про причетність Леоніда Кучми та його оточення до викрадення та вбивства журналіста Георгія Гонгадзе.

${ }^{38}$ Кольчужний скандал 2000 р. - оприлюднення інформації про ймовірний продаж Україною Іраку в обхід ембарго радарів «Кольчуга» під виглядом вантажівок.

${ }^{39}$ Касьянов Г. Украина 1991-2007: очерки новейшей истории. Киев: Наш час, 2008. С. 317-325.

${ }^{40}$ Про функціональні повноваження Прем'єр-міністра України, Першого віце-прем'єр-міністра і віцепрем'єр-міністрів України: Постанова Кабінету Міністрів України від 13.12.2002 р. № 1904. Офіційний вісник Украӥни. 2002. № 51 . С. 85.
} 
Кабміні. Цікаву статистику демонструє довідка про стан виконання розпоряджень уряду, підготовлена в червні 2003 р. Згідно з нею, з 45 доручень, виданих Кабміном за кілька місяців поточного року, Януковичу належало аж 2: аналіз співпраці України з НАТО та стан приватизації обєктів Міністерства оборони України. Ці завдання не можна віднести до стратегічних чи вкрай важливих для діяльності виконавчої влади. Більше того, вони справляють враження доручень, сформульованих «під Януковича» для імітації його управлінської діяльності. Натомість головну активність у роздачі завдань виявляли Микола Азаров (20 доручень), Дмитро Табачник (12) та Віталій Гайдук (9) ${ }^{41}$.

Тож є всі підстави вести про те, що протягом 2002-2005 рр. Янукович виконував роль «весільного генерала», уособлюючи інтереси донецького клану та готуючись до можливої боротьби за посаду Президента України в 2004 р. Реальні рішення в уряді приймали його більш досвідчені колеги. Опосередкованим свідченням цього є також активність урядових структур. Відсутність прем'єр-міністра жодним чином не впливала на активність Кабміну. Наприклад, 28 травня 2003 р. Віктор Янукович не брав участь у засіданні уряду. Головував Азаров, який ініціював розгляд 67 нормативних документів, зокрема проектів законів «Про Фонд державного майна України», про зміну обліку податку на додану вартість, Бюджетного та Житлового кодексів, прийняття програми адаптації законодавства України до законів ЄС, обговорення проблем вступу до Світової організації торгівлі ${ }^{42}$.

I навпаки, відсутність Азарова одразу впливала на інтенсивність роботи Кабміну. Зокрема, 10 вересня 2003 р. перший віце-прем'єр-міністр поїхав у відрядження. Головував Віктор Янукович. Уряд спромігся опрацювати вдвічі менше документів - 35, при чому ніяких серйозних рішень там не було ${ }^{43}$.

Ці факти ставлять під сумнів менеджерські таланти Віктора Януковича, що начебто стали причиною призначення його спочатку головою Донецької облдержадміністрації, а згодом прем'єр-міністром. Натомість ми спостерігаємо картину діяльності типової підставної особи, яка втілює рішення власних опікунів чи патронів і просто ставить підписи на офіційних документах.

Таким чином, В. Янукович мав за своїми плечима значний кримінальний досвід i, вірогідно, був завербований «чекістами». Цей досвід, зв'язки у кримінальному світі Донбасу, а також, вірогідно, покровительство «силовиків» дозволили йому пройти стрімкий шлях від політика регіонального рівня до Президента України. Перехід з регіонального рівня на республіканський рівень влади став можливий після «союзу» між чинним тоді Президентом Л. Кучмою і донецькою ФПГ. Результатом цієї співпраці стало призначення 21 листопада 2002 р. В. Януковича прем'єр-міністром України. Фактично з цього моменту розпочався повзуче захоплення «донеччанами» найвищих державних посад в Україні.

\footnotetext{
${ }^{41}$ Копія довідки про стан виконання розпоряджень КМУ від 11.06 .2003 p. №327-р. Особистий архів B.I. Денисенка.

${ }^{42}$ Копія протоколу засідання КМУ від 28.05.2003 p. № 16. Особистий архів В.I. Денисенка.

${ }^{43}$ Копія протоколу засідання КМУ від 10.09.2003 р. № 28. Особистий архів В.І. Денисенка.
} 


\section{Vadym Denysenko}

\section{Victor Yanukovych: Embarking upon a Career in Politics}

Abstract: The article presents an analytical overview of publications highlighting the fourth President of Ukraine Victor Yanukovych's life track. By combining the existing research with the newly found sources, we attempt at reconstructing the initial phase of Yanukovych's biography as a politician. Based on open sources and available evidence, we critically rethink the well-established concepts of the nature of the 1970s criminal indictment against Yanukovych resulting in his conviction and imprisonment, with specific attention paid to the subsequent conviction expungement process. The paper also links Yanukovych's late Soviet criminal experience to his rapid political ascent. We suggest that the reason behind Yanukovich's rush into regional political elite was his undercover work for security agencies. It is stated that Yanukovych's transfer to the high politics was determined by bargains between the President L. Kuchma and the Donetsk financial industrial group's representatives. Specifically, we aim to demonstrate that, while lobbying Yanukovych for the Prime-Minister of Ukraine, the Donetsk financial industrial group representatives still lacked control over his cabinet consisting mainly of the President L. Kuchma's loyalists. The research hypothesis of Yanukovych's role as a head of the Cabinet of Ministers limited to that of a client serving his patrons and getting ready for the Presidential Elections is backed by a thorough analysis of Yanukovych Cabinet's structure, HR policies and allocation of authority procedures.

Keywords: Victor Yanukovych, Donetsk clan, Leonid Kuchma, Prime Minister, financial industrial group 